\title{
Quantitative Estimation of Casein in Different Milk Samples
}

\author{
Mussarat Jabeen", Mamoona Anwar, Warisha Fatima, Adeeba Saleem, Khadija Rehman, \\ Maryum Masood, Numaira Iqbal, Saima Anjum, Ansa Madeeha Zafar, Noreen Aslam
}

Department of Chemistry, Govt. Sadiq College Women University, Bahawalpur, Pakistan

\section{Email address:}

drmussarat.jabeen@gmail.com(M. Jabeen)

${ }^{*}$ Corresponding author

\section{To cite this article:}

Mussarat Jabeen, Mamoona Anwar, Warisha Fatima, Adeeba Saleem, Khadija Rehman, Maryum Masood, Numaira Iqbal, Saima Anjum, Ansa Madeeha Zafar, Noreen Aslam. Quantitative Estimation of Casein in Different Milk Samples. Science Journal of Analytical Chemistry. Vol. 8, No. 3, 2020, pp. 107-110. doi: 10.11648/j.sjac.20200803.13

Received: June 23, 2020; Accepted: July 13, 2020; Published: July 30, 2020

\begin{abstract}
Milk is an important part of human life and supposed to be a nutritious food which contain about $80 \%$ proteins. Milk proteins consist of $80 \%$ casein (soluble protein), $2-8 \%$ lactose (milk fat) and remaining is whey (byproduct of cheese and casein manufacture). Casein is more important and contain almost all essential amino acids. The purpose of the present work was to estimate the amount of casein in different milk samples including natural milk (cow, buffalo, sheep and goat) both in boiled and un-boiled form and ultra-high temperature processed (Nestle Milk pack, Olper's and Everyday Liquid) milk. In all the milk samples Nestle Milk pack contains high casein $(\mathrm{g} / 100 \mathrm{~mL}) 7.39 \pm 0.021$ while cow milk contains lowest casein $(\mathrm{g} / 100 \mathrm{~mL})$ $4.91 \pm 0.036$ in un-boiled form and $4.75 \pm 0.025$ in boiled form. Milk is supposed to be more beneficial if quantity of casein increases. From this research it is concluded that sheep milk is more beneficial with casein percentage $5.64 \pm 0.01$ in un-boiled milk and 5.52 \pm 0.021 in boiled milk sample in case of natural milk samples while in tetra-packs Nestle Milk pack is beneficial with casein percentage $7.18 \pm 0.021$ and $7.39 \pm 0.021$ casein $(\mathrm{g} / 100 \mathrm{~mL})$.
\end{abstract}

Keywords: Casein, Milk, Precipitation, Amino Acids, Bahawalpur

\section{Introduction}

By changing the eating habits, lifestyle of people has been advanced. The people are demanding high nutritious and cheapest food resource for their proper growth and development [1]. In this perspective, milk can contribute to ensure food security. Milk is a cheapest and basic source of all valuable nutrients required for the normal body growth and the brain development [2]. Milk is a whitish liquid produced by the mammary glands of female mammals to feed or nourish their young ones [3, 4]. It is the richest and appreciable source of energy for infant mammals including human beings [5]. Milk is an excellent source of proteins, fats, vitamins, minerals and antioxidants [6]. It is a versatile ingredient used for the production of many dairy products i.e. cheese, yogurt, butter, creams, ice creams etc. [7]. It contains protein (3.4\%), lactose $(4.8 \%)$, fats $(3.6 \%)$, water $(87.5 \%)$, vitamins and minerals $(0.7 \%)$ [2]. Consumption of milk varies according to the age groups of people. There are about six billion people in the world who consume milk and other milk products [1].
Pakistan is the fifth largest milk- producing country in the world. In Pakistan 60 million metric tons of milk is being produced annually [2].

Casein is considered as a chief and major component of milk because it constitutes about $80 \%$ of milk protein $[8,9]$ while remaining are lactose and whey [10]. The main casein components involve $\alpha \mathrm{S} 1$-casein, $\alpha \mathrm{S} 2$-casein, $\beta$-casein and $\kappa$-casein $[8,10]$. It contains all the essential amino acids like Leucine $(8.3 \%)$, Lysine $(7.4 \%)$, valine $(6.5 \%)$, isoleucine (5.5\%), phenylalanine $(4.5 \%)$, threonine $(4.4 \%)$, methionine $(2.5 \%)$, tryptophan $(1.1 \%)[11,12]$. It is white amorphous solid in pure form with hydrophobic interactions which make it water- insoluble [13]. It is tasteless, odorless with isoelectric pH $4.6[14,15]$. In milk, calcium phosphate and casein form colloidal particles called casein micelles $[7,16]$. The richest profile of amino acids present in the casein shows that it is a valuable source of energy for the development of the brain and the strengthening of muscles and bones [17]. Casein is also used for the manufacturing of dairy products i.e. cheese, curd, ice-creams, milkshakes etc. [8, 18] Besides its nutritional 
value, casein have many other uses like binders in processed meat, paper coating, glues, the dressing of leather and man-made fibers [19].

By knowing the importance of casein, the aim of this paper is to estimate the amount of casein in natural (cow, buffalo, sheep and goat) in boiled and un-boiled form and UHT treated (Nestle Milk pack, Olper's and Everyday Liquid) milk samples.

\section{Experimental}

\subsection{Milk Samples}

Eleven milk samples were collected from local market of Bahawalpur City. In these samples natural milk as well as artificial milk means powdered milk was used to estimate the casein concentration. These milk samples were placed in ice and dispatched to Analytical Laboratory of Department of Chemistry, Govt. Sadiq College Women University Bahawalpur. Before working, all the milk samples were filtered to remove insoluble impurities like hair, dirt etc.

\subsection{Casein Precipitation}

$100 \mathrm{ml}$ of each milk sample was heated between $50-60{ }^{\circ} \mathrm{C}$ for about 5 minute. One percent acetic acid was slowly added with constant stirring. $\mathrm{pH}$ of each sample must be 4.6-4.7 and checked by $\mathrm{pH}$ meter. Samples were kept undisturbed for 10-15 minutes at room temperature. Precipitates of acid casein were filtered and washed with methanol to remove fats. Casein in the form of white amorphous substance was dried to calculate percentage yield. The experiments were performed in triplicate and percentage of casein was calculated by using the equation given below.

$$
\text { percentage yeild of Casein }=\frac{\text { weight of casein }(g)}{\text { weight of milk }(g)} \times 100
$$

\section{Results and Discussions}

According to the literature, milk with high concentration of casein is more beneficial as compared to low concentration. To evaluate the concentration of casein in milk, 11 milk samples were studied including natural milk in boiled and un-boiled form as well as ultra-high temperature treated milk usually known as tetra-packs. Before estimation, these samples were stored in ice and filtered to remove suspended impurities. As reported, casein concentration varies in milk samples ranging up to $80 \%$. Casein in the form of white amorphous solid was collected and dried in desiccator. The results showed (Table 1, Table 2, Figure 1 and Figure 2) that sheep milk contains high amount of casein $(\mathrm{g} / 100 \mathrm{~mL})$ $5.81 \pm 0.01$ with casein percentage $5.64 \pm 0.01$ and $5.69 \pm 0.021$ casein $(\mathrm{g} / 100 \mathrm{~mL})$ and $5.52 \pm 0.021$ casein percentage in un-boiled and boiled milk samples among natural milk.
Similarly, buffalo milk is also beneficial with casein concentration $(\mathrm{g} / 100 \mathrm{~mL}) 5.71 \pm 0.03$ and $5.62 \pm 0.025$ with casein percentage $5.54 \pm 0.03$ and $5.46 \pm 0.025$ in un- boiled and boiled milk samples respectively. Cow milk contains lowest casein concentration $(\mathrm{g} / 100 \mathrm{~mL}) 4.91 \pm 0.036$ and $4.75 \pm 0.025$ with casein percentage $4.77 \pm 0.036$ and $4.61 \pm 0.25$ among un-boiled and boiled milk samples. In case of UHT treated milk (tetra pack) samples, Nestle milk pack contains highest concentration of casein while olper milk contain lowest concentration $7.39 \pm 0.021$ and $5.36 \pm 0.021$ with casein percentage $7.18 \pm 0.021$ and $5.21 \pm 0.026$ respectively.

From the given results, it is confirmed that buffalo milk contain more casein as compared to cow milk and sheep milk contain more casein as compared to goat milk. Among all these natural milk samples, sheep milk is supposed to be more beneficial both in boiled and un-boiled form. While both of these have low concentration of casein as compared to UHT treated Nestle milk pack. Among tetra packs, Nestle milk pack is supposed to be more beneficial as compared to Olper's and Everyday milk.

Sheep milk $>$ buffalo milk $>$ goat milk $>$ cow milk

Nestle Milk pack $>$ Everyday milk $>$ Olper's milk

Casein concentration in all milk samples is simply expressed as

Nestle Milk pack $>$ Everyday milk $>$ Sheep milk $>$ Buffalo milk $>$ Goat milk $>$ Olper's milk $>$ cow milk

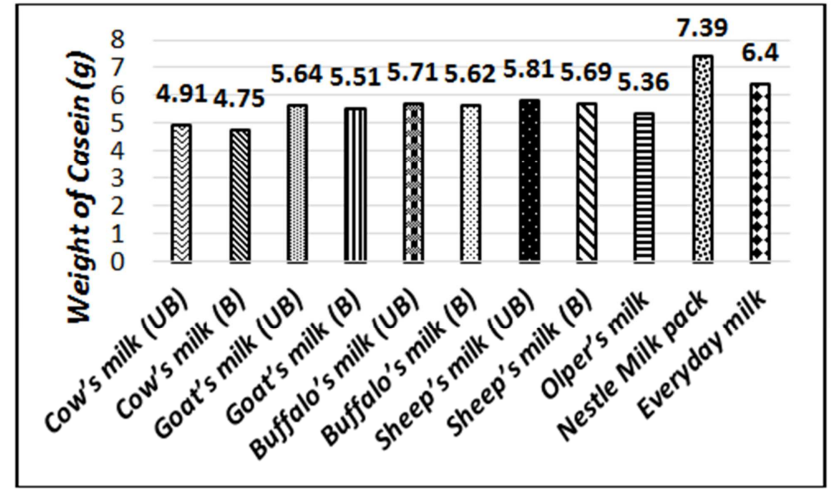

Figure 1. Graph to show the weight of casein $(g)$ in different milk sample.

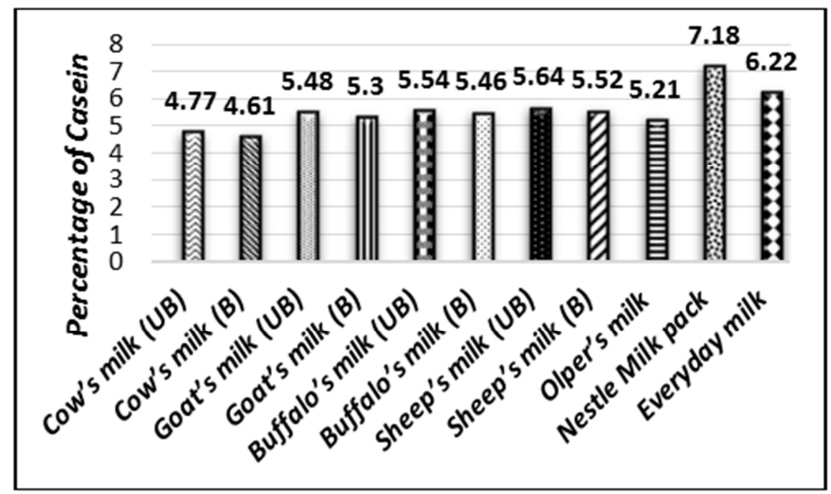

Figure 2. Graph to show the percentage of casein in different milk sample. 
Table 1. Weight of Casein in different Milk samples.

\begin{tabular}{llllll}
\hline \multirow{2}{*}{ Serial No } & \multirow{2}{*}{ Milk Sample } & \multicolumn{2}{l}{ Weight of Casein (g) } & Sample (3) & Mean \pm SD \\
\cline { 3 - 5 } & & Sample (1) & Sample (2) & 4.94 & $4.91 \pm 0.036$ \\
\hline 1 & Cow's milk (UB) & 4.87 & 4.92 & 4.78 & $5.75 \pm 0.025$ \\
2 & Cow's milk (B) & 4.75 & 4.73 & 5.66 & $5.64 \pm 0.025$ \\
3 & Goat's milk (UB) & 5.64 & 5.61 & 5.5 & $5.51 \pm 0.015$ \\
4 & Goat's milk (B) & 5.51 & 5.53 & 5.74 & $5.71 \pm 0.03$ \\
5 & Buffalo's milk (UB) & 5.7 & 5.68 & 5.6 & $5.62 \pm 0.025$ \\
6 & Buffalo's milk (B) & 5.62 & 5.65 & 5.82 & $5.81 \pm 0.01$ \\
7 & Sheep's milk (UB) & 5.81 & 5.8 & 5.71 & $5.69 \pm 0.021$ \\
8 & Sheep's milk (B) & 5.68 & 5.67 & 5.39 & $5.36 \pm 0.026$ \\
9 & Olper's milk & 5.35 & 5.34 & 7.42 & $7.39 \pm 0.021$ \\
10 & Nestle Milk pack & 7.38 & 7.39 & 6.43 & $6.4 \pm 0.015$ \\
11 & Everyday milk & 6.42 & 6.4 & & \\
\hline
\end{tabular}

Density of Milk $=1.029 \mathrm{~kg} / \mathrm{L}, \mathrm{UB}=$ un-boiled, $\mathrm{B}=$ boiled, $\mathrm{SD}=$ standard deviation

Table 2. Percentage of Casein in different Milk samples.

\begin{tabular}{|c|c|c|c|c|c|}
\hline \multirow{2}{*}{ Serial No } & \multirow{2}{*}{ Milk Sample } & \multicolumn{4}{|c|}{ Percentage of Casein } \\
\hline & & Sample (1) & Sample (2) & Sample (3) & Mean \pm SD \\
\hline 1 & Cow's milk (UB) & 4.73 & 4.78 & 4.8 & $4.77 \pm 0.036$ \\
\hline 2 & Cow's milk (B) & 4.61 & 4.59 & 4.64 & $4.61 \pm 0 . .25$ \\
\hline 3 & Goat's milk (UB) & 5.48 & 5.45 & 5.5 & $5.48 \pm 0.025$ \\
\hline 4 & Goat's milk (B) & 5.35 & 5.37 & 5.34 & $5.3 \pm 0.015$ \\
\hline 5 & Buffalo's milk (UB) & 5.54 & 5.52 & 5.58 & $5.54 \pm 0.03$ \\
\hline 6 & Buffalo's milk (B) & 5.46 & 5.49 & 5.44 & $5.46 \pm 0.025$ \\
\hline 7 & Sheep's milk (UB) & 5.64 & 5.63 & 5.65 & $5.64 \pm 0.01$ \\
\hline 8 & Sheep's milk (B) & 5.52 & 5.51 & 5.55 & $5.52 \pm 0.021$ \\
\hline 9 & Olper's milk & 5.2 & 5.19 & 5.24 & $5.21 \pm 0.026$ \\
\hline 10 & Nestle Milk pack & 7.17 & 7.18 & 7.21 & $7.18 \pm 0.021$ \\
\hline 11 & Everyday milk & 6.24 & 6.22 & 6.25 & $6.22 \pm 0.015$ \\
\hline
\end{tabular}

Density of Milk=1.029kg $/ \mathrm{L}, \mathrm{UB}=$ un-boiled, $\mathrm{B}=$ boiled, $\mathrm{SD}=$ standard deviation

\section{Conclusion}

As casein is major protein present in milk, contains almost all essential amino acids and important for digestion, growth and development. From this study, it is concluded that sheep milk is more beneficial for humans as compared to cow, buffalo and goat milk as it contains high amount of casein $(\mathrm{g} / 100 \mathrm{~mL}) 5.81 \pm 0.01$ in un-boiled form and $5.69 \pm 0.021$ in boiled sample than other natural milk samples. The casein percentage in sheep milk is also highest 5.64 \pm 0.01 \& $5.52 \pm 0.021$ in un-boiled and boiled milk samples respectively. Similarly, Nestle Milk pack contain high casein amount (g/100mL) 7.39 \pm 0.021 than Olper's (5.36 \pm 0.02$)$ and Everyday milk $(6.4 \pm 0.015)$ and supposed to be more beneficial than other's tetra packs available in market.

\section{Acknowledgements}

Authors have no conflict for publishing this article and acknowledges The Government Sadiq College Women University, Bahawalpur for providing chemicals. Authors are grateful to Prof. Dr. Ashfaq Mahmood Qureshi (Dean of Sciences) and Dr. Farzana Wajid Khan (Chairperson), Department of Chemistry, Government Sadiq College Women University Bahawalpur for their support in this research work.

\section{References}

[1] A. Kumaresan, C. Selma, N. V. Reshma and N. A. Jacinth. (2017). Quantitative Analysis of Casein Precipitation from the Various Milk Samples, J. chem. pharm. Res., 9113.

[2] M. Ayub, Q. Ahmad, M. Abbas, I. M. Qazi and I. A. Khattak. (2007). Composition and Adulteration Analysis of Milk Samples, SJA, 231127.

[3] N. Jamil, M. Riaz, S. Rizwan, Z. Masood, U. Jabeen, A. Mushtaq, F. Iqbal, W. Razzaq, M. Khan, Z. mannan, P. Khan, R. Shah and K. Nasir. (2015). Comparative Study of Casein and Lactose in Processed and Unprocessed Milk Samples from Quetta, Glob. Vet., 14876.

[4] C. P. Kulkarni. (2017). Analysis of casein precipitation from the various milk samples available in market, Int. J. Food Sci. Nutr., 22455.

[5] M. Borková and J. Snášelová. (2005). Possibilities of Different Animal Milk Detection in Milkand Dairy Products - a Review, Czech J. Food Sci., 2341.

[6] K. Musayeva, A. Sederevičius, R. Želvyte, I. MonKevičienė, D. BeliavsKa-Ale Ksiejūnè and R. StanKevičius. (2016). Relationship between Somatic Cell Count and Milk Casein Level Obtained by Two Different Methods, Czech J. Food Sci., 3447. 
[7] S. Patil, S. S. Hosapete, S. Irkal and S. Rajput. (2019). Analysis of Casein from Diffent Samples of Milk, IOSR JAC, 1223.

[8] B. Ribadeau-Dumas and R. Grappin. (1989). Milk protein analysis, Lait, 69357.

[9] S. Muller-Renaud, D. Dupont and P. Dulieu. (2003). Quantification of $\kappa$-casein in milk by an optical immunosensor, Food Agr. Immunol., 15265.

[10] L. Ruprichová, G. Tompa, M. Králová, I. Borkovcová, I. Bedáňová and L. Vorlová. (2015). Profiling of caseins in cows', goats' and ewes' milk and dairy products by reversed-phase high-performance liquid chromatography, J. Food Nutr. Res., 54218.

[11] C. Rodica and C. Annica. (2008). Comparative Study on Milk Casein Assay Methods, Lucrări ştiinNificice Zootehnie şi Biotehnologii, 41758 .

[12] H. B. Vickery and A. White. (1933). The Basic Amino Acids of Casein, J. Biol. Chem., 103413.

[13] J. Jakubowski, Z. Sienkiewicz and E. Nowak. (1985). Rapid Determination of Casein in Milk, Nature, 1811277.
[14] D. M. Barbano and J. M. Lynch. (2006). Major Advances in Testing of Dairy Products: Milk Component and Dairy Product Attribute Testing, J. Dairy Sci., 891189.

[15] D. M. Barbano and M. E. Dellavalle. (1987). Rapid Method for Determination of Milk Casein Content by Infrared Analysis $J$. Dairy Sci., 701524.

[16] C.-H. Yen, Y.-S. Lin and C.-F. Tu. (2015). A Novel Method for Separation of Caseins from Milk by Phosphates Precipitation, Prep Biochem Biotech., 4518.

[17] R. Kala, E. Samková, O. Hanuš, L. Pecová, K. Sekmokas and D. Riaukienè. (2019). Milk Protein Analysis: An Overview of The Methods - Development and Application, Acta Univ. Agric. Silvic. Mendel. Brun., 67345.

[18] F. W. Douglas, J. Tobias, M. L. Groves, H. M. Farrell and L. F. Edmondson. (1982). Quantitative Determination of Total Protein, Casein, and Whey Protein of Processed Dairy Products, J. Dairy Sci., 65339.

[19] J.-L. Audic, B. Chaufer and G. Daufin. (2003). Non-food applications of milk components and dairy co-products: A review, Lait, 83417. 